\title{
Strategic entrepreneurial choice between competing crowdfunding platforms
}

\author{
Jerry Coakley $^{1}$ (D) Aristogenis Lazos ${ }^{2} \cdot$ Jose Liñares-Zegarra $^{1}$
}

Accepted: 29 September 2021 / Published online: 19 October 2021

(c) The Author(s) 2021

\begin{abstract}
This paper investigates strategic entrepreneurial choice between the UK Big 3 platformsCrowdcube, Seedrs and SyndicateRoom-that exemplify the three main equity crowdfunding (ECF) shareholder structures identified in the literature. ECF has become a strategic choice for both entrepreneurs and angel and venture capital funds as it offers mutually beneficial advantages to both, especially under the co-investment ECF model where these funds co-invest alongside the crowd. The multinomial probit results show that large founder teams are more likely to choose the co-investment model (SyndicateRoom) but are less likely to opt for the nominee ownership structure (Seedrs). Although less heterogeneous teams are more likely to choose the Seedrs and Crowdcube ownership structures, our results suggest that the probability of choosing the co-investment model (SyndicateRoom) monotonically increases as teams become more heterogeneous. The conclusion is that larger and heterogeneous teams are more likely to raise ECF funds from campaigns explicitly involving professional investors.
\end{abstract}

Keywords Equity crowdfunding $\cdot$ Founder team $\cdot$ Platforms $\cdot$ Shareholder structures

JEL Classification G240 · M130

We are grateful to an anonymous referee and to Silvio Vismara for their helpful and constructive comments which substantially improved the exposition of the paper.

Jerry Coakley

jcoakley@essex.ac.uk

Aristogenis Lazos

alazos@audencia.com

Jose Liñares-Zegarra

jmlina@essex.ac.uk

1 Essex Business School, University of Essex, Colchester, UK

2 Finance Department, Audencia Business School, Nantes, France 


\section{Introduction}

Young startups and ventures can raise outside equity from a variety of sources in the entrepreneurial finance market (see Cassar, 2004; Cooper et al, 1994; Schwienbacher, 2013). The traditional sources include business angel (BA), venture capital (VC), and private equity (PE) investors. Over the past decade, equity crowdfunding (ECF) has emerged as a novel source of outside equity in an effort to democratize entrepreneurial finance (Kleinert \& Mochkabadi, 2021). It may have the advantage of being stable and resilient in period of crisis (Cumming et al, 2021), and was initially provided by a geographically dispersed crowd of mainly non-accredited investors who exhibit heterogeneity in their investments (Hornuf et al., 2021). In this context, ECF has been viewed by some as an equity funding mode of last resort for discouraged entrepreneurs based on a pecking order view of outside finance (Walthoff-Borm et al., 2018a). The implication of this view is that the platform's main role is to act as gatekeepers to mitigate adverse selection problems and thus protect the crowd. The above study analyses early (2012-15) campaigns in the UK when the pure ECF model (where institutional investment was absent/ minimal) still prevailed. For example, Zhang et al. (2018) find that the share of accredited institutional investors such as BA and VC in UK ECF was a mere $8 \%$ in 2015 . However, with the rise of co-investment in ECF campaigns, their share rose to $25 \%$ in 2016 and to $49 \%$ in 2017 and levelled off at around 50\% since (Zhang et al., 2018). This level of institutional involvement in ECF casts doubt on the notion of ECF as equity funding of last resort in the post-2016 period.

In this context, other researchers argue that ECF may be a strategic or first choice rather than a last resort for startups (Cummings et al., 2020; Junge et al., 2021; Stevenson et al., 2021). Stevenson et al. (2021) focus on the concept of entrepreneurs as strategic fund seekers rather than as startups striving to satisfy the criteria of traditional funders like BA or VC. They argue that strategic entrepreneurs seek "funding fit" by choosing ECF for reasons that highlight new forms of nonfinancial value. We complement that by pointing to the attractions of ECF campaigns for entrepreneurs. ECF enables them to raise BA/VC funding more cheaply as the latter co-invest at the share price agreed with the platform and platform fees are lower than BA or VC syndicate fees. Traditional BA or VC funders as sole funders use their positions as monopoly providers and to lowball the purchase price for their stakes and also enjoy power vis-à-vis the entrepreneur in the aftermath of their stakes. This is a very important value consideration that is not discussed in the Stevenson et al. (2021) study.

This paper adopts the view of entrepreneurs as strategic fund seekers but in the context of the highly developed ECF market in the UK. This market has two distinctive features. The first is that this has been a predominantly coinvestment ECF market since 2016 (Zhang et al., 2018). BA, VC, PE and other early stage investors such as family offices widely invest in ECF campaigns and often pre-commit funds prior to campaigns going public. Coinvestment has attractions for both traditional investors and for the startups. On the one hand, BA and VC funds can diversify their investments across a wider number of startups by making smaller but still significant contributions to a larger number of ECF campaigns. On the other, these smaller equity stakes imply that entrepreneurs are less subject to direct control by such investors than in the traditional BA or VC stakes (except for the SyndicateRoom co-investment model-see below). Moreover, BA or VC stakes provide certification effects that attract more crowd investors (Ralcheva \& Roosenboom, 2016). This paper complements and extends their study by highlighting value and control considerations in funding fit choice in the context of the UK ECF market. 
The second feature of the UK market is its very distinctive ownership structures embedded within ECF platforms that provide a wide choice to strategic entrepreneurs seeking outside equity. Cumming, Vanacker and Zahra (2019c) highlight that ECF platforms embrace the three shareholder structures that are adopted by the Big 3 UK ECF platforms. The first is the direct ownership scheme pioneered by Crowdcube-the UK's largest ECF platform-since 2011 where the investors are the legal and beneficial owners. The second or nominee account model introduced by Seedrs in 2012 is one where the platform as legal owner acts on behalf of all the investors who are the beneficial owners. The nominee model involves an active post-campaign corporate governance role for the platform (Coakley et al., 2021a). The third ECF model is the co-investment or lead investor model pioneered by SyndicateRoom in 2014 . Here the lead investor conducts due diligence, commits $25-40 \%$ of the target capital prior to the campaign going public and monitors the ECF firm in the wake of a successful campaign. ${ }^{1}$

Over time, the distinctions between platforms has lessened. Each of the platforms has adopted some of the features of their rivals. One notable feature formally adopted by all Big 3 platforms is the co-investment model or what is called private launch by Seedrs and Crowdcube. ${ }^{2}$ This is most developed in the case of SyndicateRoom where it is known as the lead investor model but elements of it were later adopted by the other two platforms. The significant difference is that due diligence is led by the professional investor. Thus, one can argue that the UK market has become a predominantly co-investment rather than a pure ECF market in that BA, VC, PE and other early stage investors such as family offices widely invest in ECF campaigns and often pre-commit funds prior to campaigns going public. Apart from the Zhang et al. (2018) data referred to above, the British Business Angel Association estimate that approximately one third of all UK and 43\% of Londonbased business angels have co-invested on ECF platforms. These levels of co-investment based on thorough due diligence are clearly at odds with the view of ECF as equity of last resort. Rather they suggest that both ECF platforms and traditional equity providers are developing synergistic relationships in the seed and growth stage financing ecosystem.

The paper's major contribution is that it analyses the details of strategic entrepreneurial choice among distinctive ECF platforms as their preferred outside equity option. Co-investment is key here as this step often precedes the public launch of UK initial ECF campaigns in recent years. On the one hand, it enables entrepreneurs to focus on the post-campaign shareholder structure they want for their startups as they transition to what Cumming et al. (2021) call the ECF firm, while on the other, they may strategically choose a platform to signal quality and increase the likelihood of campaign success. Thus, our paper complements the Stevenson et al. (2021) study by analysing founder team choice among three competing platform structures employing a large quantitative dataset. The study employs data from 1291 (successful and unsuccessful) initial campaigns that have been conducted on Crowdcube, Seedrs and SyndicateRoom over the 2013-2018 period. It broadly follows Chemmanur and Paeglis (2005) in quantifying founder (management) team characteristics and in highlighting team heterogeneity. ${ }^{3}$ They proxy management team resources by team

\footnotetext{
1 SyndicateRoom ceased to be a crowdfunding platform in late 2019—-see Coakley and Lazos (2021)

${ }^{2}$ See https://help.crowdcube.com/hc/en-us/articles/115001114890-Your-Crowdcube-journey and https:// help-entrepreneur.seedrs.com/en/articles/2127314-is-my-campaign-ready-for-private-launch

3 Note that they focus on the relation between management quality and Initial Public Offerings and document a positive association between quality and IPO outcomes. Vismara (2018) notes that IPOs share common features with ECF campaigns.
} 
size and qualifications (e.g. holding an MBA) and team heterogeneity by average tenure and tenure heterogeneity. In addition, we employ proxies capturing age and nationality heterogeneity.

The results suggest that founder team size is negatively associated with the probability of choosing the Seedrs nominee model and with a significantly higher probability of choosing the Syndicate Room co-investment model. One obvious attraction of Seedrs for solo founders and small teams is that the platform as nominee assumes responsibility for all corporate governance and related administrative tasks. Our results complement and lend support to the findings in Cumming et al. (2019b) in which ownership structures are an important determinant of success.

The average marginal effects for team heterogeneity (tenure, nationality and age) are all positive and significant at the $1 \%$ level. They imply a higher probability of choosing the SyndicateRoom co-investment shareholder structure across all models, highlighting the role of a business angel as lead investor on this platform. By contrast, heterogeneous teams are less likely to pick the Seedrs nominee platform for their initial campaign. The clear implication is that larger and heterogeneous teams are more likely to raise ECF funds from campaigns explicitly involving professional investors.

The rest of the paper is organized as follows. Section 2 discusses the relevant literature and outlines the hypotheses to be tested. Section 3 gives details of our data and empirical methodology. Section 4 discusses the results of multinomial probit analysis while the final section concludes.

\section{Literature and hypotheses}

This section provides first a brief summary of the UK ECF platform structures and then discusses existing literature findings. Finally, it formulates hypotheses that will be tested in the empirical section. It argues that founder team with specific characteristics may choose strategically a specific platform to signal startup quality.

\subsection{UK ECF platform structures}

There is a growing interest in the equity crowdfunding (ECF) literature in both corporate governance and competing platform shareholder structures. Studying them has become fundamental (Buttice \& Vismara, 2021). Cumming, Vanacker and Zahra (2019c) highlight that ECF platforms embrace the three shareholder structures that are adopted by the Big 3 UK ECF platforms. The first is the direct ownership scheme pioneered by Crowdcube - the UK's largest ECF platform-since 2011. Here the platform's post-campaign role as an intermediary is minimal and so the startup directly communicates with its investors who are the legal owners. The big attraction of this model is that the ECF shareholders enjoy direct (legal) ownership of the shares and their names appear on the share register. However, it also has downsides. One is that post-campaign corporate governance (e.g. decision making on a host of issues such as calling extraordinary meetings or decisions about follow-on funding) can impose a heavy administrative burden especially in the case of large shareholder numbers. Another is the challenges of attracting large investments to provide ECF campaigns with traction in their early stages. This may have an impact on the type of investor it may attract in the future (Buttice et al., 2021). 
The second or nominee account model introduced by Seedrs in 2012 is one where the platform as legal owner acts on behalf of all the investors who are the beneficial owners. The nominee model involves an active post-campaign corporate governance. Coakley et al. (2021a) discuss the role of the nominee model and conceptualise it as having similarities with venture capital (VC) or business angel (BA) syndicates. However, both VC and BA syndicates are limited to qualified (professional and high net worth) investors. The latter have to pay fees of between 5 and $20 \%$ to the syndicate lead investor on AngelList and an additional 5\% to the platform (Agrawal et al., 2016). By contrast, Seedrs nominee campaigns encourage the involvements of ordinary investors- the crowd-by granting them full voting and ownership rights and also involve low campaign fees.

The third ECF model is the co-investment or lead investor model pioneered by SyndicateRoom in 2014. Its model resembles the BA syndicate in being open to qualified investors only but its campaign fees are similar to those of Seedrs and Crowdcube. Here the lead investor conducts due diligence as well as committing $25-40 \%$ of the target capital prior to the campaign going public. The SyndicateRoom model is closer to the VC/BA syndicate in that its campaigns are limited to qualified investors only, but it only charges a nominal fee for participating in a campaign.

\subsection{Related literature}

This paper links to a number of distinct literatures. The first and most central of these is the role of the founder team in young startups and ventures. While the central role of the founder team has not yet been widely investigated in the ECF context, it has received considerable attention in later stage entrepreneurial financing. When a new firm is founded, one of the most important factors that provides the basis for its success is its founder team. The existing literature establishes that the founder team composition is possibly the most important factor for the long-term success of a firm (Eisenhardt \& Schoonhoven, 1990; SØrensen and Stuart, 2000; Agarwal et al., 2020).

One interesting question in this literature is whether solo ventures outperform founder teams. In general, the results suggest that teams perform better than solo founders because of the wider set of skills they possess (Lazear, 2005; Levine et al., 2017). One notable exception is the paper by Greenberg and Mollick (2018). They find that solo founders outperform founder teams in terms of survival and do no worse in terms of revenue generation using a sample reward-based crowdfunding campaigns on Kickstarter. However, since reward-based crowdfunding campaigns are generally less risky than ECF campaigns (Coakley and Lazos, 2021), it may not be possible to generalise these findings.

In this vein, Coakley et al., (2021c) examine whether solo founders are more likely than founder teams to succeed in an initial ECF campaign and subsequently are less likely to fail. The results for a large sample of initial ECF campaigns on the Crowdcube, Seedrs and SyndicateRoom platforms show that solo founders have a lower probability of conducting successful initial ECF offerings than founder teams and have a higher probability to fail in the long run. They conjecture that founder teams enjoy more success as their human capital quality may likely attract professional investors that can act as a certification effect. Moreover, the monitoring role of professional investors helps to minimise moral hazard concerns and lowers the probability of failure for founder teams. In contrast with their study, this one is based on a pre-campaign decision-making setting where teams choose shareholder structures (platforms) and extends the range of team characteristics. It also includes a continuous team size variable rather than a binary variable capturing founder team versus solo 
founder firms, which also allows us to identify how small changes in the number of team members could potentially affect the strategic entrepreneurial choice between competing crowdfunding platforms.

This paper is also linked to a long-lasting debate (and literature) on whether management team heterogeneity-sometimes also called diversity-positively or negatively affects the performance of publicly traded firms. The empirical results are mixed. On the one hand, one strand of the literature documents a negative effect of team heterogeneity on performance (Chrobot-Mason et al., 2009; Li \& Hambrick, 2005). On the other, a different strand finds a positive effect on performance (Bantel \& Jackson, 1989; Murray, 1989). Jin et al. (2017) acknowledge the mixed results about diversity and argue that entrepreneurial teams are closely related to project teams in which there is a need for diversity. They conduct a meta-analysis study in an entrepreneurial setting and find that diversity positively affects venture performance.

The other literature to which our paper connects is that on ECF shareholder structures. A few studies have examined shareholder structures both within and across platforms. Cumming et al. (2019b) employ data from the Crowdcube platform and their two stage Heckman results suggest that ownership and control separation from its dual class share structure lowers the likelihood of both short- and long-term success. Coakley et al. (2021a) investigate both the inter-platform and intra-platform impact of nominee versus direct ownership initial campaigns. They establish that nominee initial campaigns are more likely to succeed, raise more funds, and to attract overfunding relative to direct ownership campaigns. They also find that nominee campaigns enjoy greater long run success in terms of successful seasoned equity crowdfunded offerings. Our study both complements this study and extends it by analysing the full range of platform shareholder structures available in the UK in a pre-campaign context.

Rossi et al. (2019) employ data from a sample of 185 platforms in Australia, Austria, Canada, France, Germany, Italy, New Zealand, the UK and the US. Their empirical findings establish that the direct ownership approach has a negative effect on campaign success while the nominee account approach has no significant effect in this regard. WalthoffBorm et al. (2018b) find that ECF firms which employ the nominee account realize lower losses. There has been less research on the co-investment shareholder structure model possibly because, as Rossi et al. (2019) point out, fewer campaigns have been conducted on co-investment or syndicate-like platforms. For this reason, it is important to include such a platform in our study. The importance of co-investment is highlighted in Wang et al. (2019) in which professional investors exchange information with the crowd which in turn may improve the efficiency of the ECF market.

\subsection{Hypotheses}

\subsubsection{Team size}

Co-investment. Signalling theory posits a direct association between signaller quality and signal effectiveness (Spence, 1973). Existing ECF literature suggest that founder teams are high quality signallers who are able to send effective signals that reduce information asymmetry. As a result, they are more likely to conduct successful offerings (Ahlers et al, 2015; Vismara, 2016). Thus, large size teams may choose strategically to raise capital via the co-investment model to strengthen further their signal of quality via the presence of professional investor (Ralcheva and Rossenboom 2016). Moreover, it is easier for them to comply 
with and satisfy professional investor due diligence. Solo founders for example, are less attractive for Angels and Venture Capitalists (Graham, 2006). This leads to the following hypothesis:

H1A Founder team size is positively associated with the probability of choosing the (SyndicateRoom) co-investment shareholder structure.

Nominee Solo founders and small founder teams are the least well equipped to cope with the post-initial campaign administrative burden associated good corporate governance especially when they have raised outside equity involving an ECF direct ownership campaign. For this reason, there are good grounds for leading one to presuppose that will choose a nominee platform structure (e.g. Seedrs platform) that will assume this administrative burden on their behalf if the campaign is successful. This is further supported by findings in Rossi and Vismara (2018) in which post-campaign services matter for campaign outcomes. Conversely, the size of the founder team is expected to be inversely associated with the nominee shareholder structure as larger teams can more readily share the administrative tasks.

H1B Founder team size is inversely associated with the probability of choosing the (Seedrs) nominee shareholder structure.

\subsubsection{Team heterogeneity}

A strand in the literature focuses on whether the founder (management) team matters most in professional investor investment criteria. A recent study by Gompers et al. (2020) argues that the management team is the most important criterion in selecting investments based on responses to a survey of 885 institutional venture capitalists (VCs) across 681 firms. Even though results are mixed about the association between heterogeneity-sometimes called diversity — and team performance, a meta-analysis study by Jin et al. (2017) concludes that diversity positively affects venture performance. This suggests a positive relation between heterogeneity and team quality.

There is evidence in ECF firms backed by a professional investor are less likely to fail (Signori \& Vismara, 2018). Most investments in startups take place via a professional investor network (Gompers et al., 2020). Heterogeneous teams consist of members from different cohorts and so they are more likely to have large networks that can be multi-beneficial (Wood et al, 2019). Networks matter for ECF success as well (Vismara, 2016). On the one hand, heterogeneity reflects quality in the startup ecosystem while, on the other, it is more likely for heterogeneous team to be part of a professional investor network. This makes it more likely for heterogeneous teams to choose strategically-and pass the professional investor due diligence step-to raise capital via the co-investment model in order to signal quality. This suggests the following hypothesis:

H2 Founder team heterogeneity is associated with a higher probability of choosing the (SyndicateRoom) coinvestment shareholder structure. 


\subsubsection{Team advanced education and experience}

Management literature suggests that advanced education and experience are key factors in founder team human capital. The general consensus is that highly educated and experienced teams perform well compared to their less skilled and experienced counterparts. In other words, they represent high quality signallers who are able to send effective signals to investors and raise capital successfully. Existing evidence suggest that experience is one of the most important selection criteria for VCs (Zacharakis and Meyer, 2000). Education matters for the involvement of professional investors especially in the technology sector (Levie and Gimmon, 2008) which dominates ECF (Coakley et al., 2021b). In other words, founders with these characteristics are more likely to meet professional investor investment criteria.

Experience and education play a very important role in entrepreneurial finance. The empirical studies of Barbi and Mattioli (2019) and Piva and Rossi-Lamastra (2018) show that this holds in ECF campaigns also. They argue that past experience and educational level are the most salient team human capital elements in this respect. This is particularly likely to be the case for startups engaged in complex (e.g. bio-sciences or technology) projects that may benefit from professional investor advice as on the SyndicateRoom platform. As a result, experienced and highly educated teams may choose strategically the co-investment platform to strength signal quality. This leads to the following hypothesis.

H3 Founder team experience and advanced education are associated with a higher probability of choosing the (SyndicateRoom) co-investment shareholder structure.

\section{Data and methodology}

\subsection{Data}

Our empirical results are based on a sample of successful and unsuccessful ECF campaigns launched on the three major platforms of the UK (Crowdcube, Seedrs and SyndicateRoom) covering the period 2013-2018. The data end in 2018 as SyndicateRoom changed from being a crowdfunding platform to become a fund management firm specialising in startups in 2019. This study obtains ECF data from TAB, which has been used in previous ECF studies (Ralcheva \& Roosenboom, 2019). The unique registration number for UK firms is used to match TAB data with founder data from the UK Companies House. We follow a similar approach as in Coakley et al. (2021b) and identify a founding team member to be the one listed as Director on the UK Companies House website. We remove Seasoned Equity crowdfunded offerings. This results in a dataset that consist of 1291 initial ECF campaigns.

\subsection{Empirical specifications}

In investigating the effect of founder team characteristics such as team size and heterogeneity on ECF platform choice, we conjecture that strategic founder teams may opt out for one of the three main shareholder structures that platforms offer in the UK ECF market: Crowdcube, Seedrs or SyndicateRoom. This type of decision-making process leads us to 
model platform choice by employing a multinomial probit (MNP) regression. The MNP model is used with discrete dependent variables that take on more than two outcomes that do not have a natural ordering (Cameron \& Trivedi, 2005).

Based on our analytical framework, we can assume firm $i$ 's utility for choosing platform $j, U_{i j}(i=1, \ldots, n ; j=1,2,3)$ is a function of team, firm-level and campaign characteristics and a stochastic error. The utility of choosing ECF platform $j$ is:

$$
U_{i j}=x_{i j}^{\prime} \beta+\varepsilon_{i j}
$$

where $x_{i j}$ is a vector of covariates and the errors are assumed to be normally distributed, with $\varepsilon \sim N(0, \Sigma)$ where $\varepsilon=\left(\varepsilon_{i 1}, \varepsilon_{i 2}, \varepsilon_{i 3}\right)$. The probability that platform $j$ is chosen is

$$
p_{i j}=\operatorname{Pr}\left(y_{i}=j\right)=\operatorname{Pr}\left\{\varepsilon_{i k}-\varepsilon_{i j} \leq\left(x_{i j}-x_{i k}\right)^{\prime} \beta\right\} \text {,forallk }
$$

where $y_{i}$ is a random variable that indicates the choice made. The MNP model is an extension of the binary probit model that allows the coefficients of the explanatory variables to vary across the choices and allow us to assess whether team size and founder team heterogeneity characteristics are associated with higher probabilities of choosing a specific platform by firms. Since we are not interested in the coefficients of the multinomial model per se but rather in the change in the probability associated to changes in team characteristics, the results are presented in terms of average marginal effects (AME). ${ }^{4}$

\subsection{Variables}

In the multinomial framework, the dependent has three outcomes associated with each particular platform shareholder structure: Crowdcube (direct ownership model), Seedrs (nominee model) and SyndicatedRoom (co-investment model). In the direct ownership model on Crowdcube, the investors become the direct owners of the shares although only a small proportion of the owners - typically those with large investments-enjoy voting rights leading to a wedge between ownership and control rights. ${ }^{5}$ In our sample, startup firms can choose between any of these platforms to launch their initial ECF campaigns. We conceptualize their choice as a categorical variable ranging from 1 to 3: (1) Crowdcube, (2) Seedrs and (3) SyndicatedRoom. The key independent variables used in the empirical model relate to team size, team heterogeneity and firm and campaign level characteristics.

A set of control variables is used to account for unobserved heterogeneity relying on the findings of existing studies. They are firm (pre-money) valuation, start-up status, headquarters location based on a London dummy, diversification across sectors, technology dummy capturing whether the firm operates in the Technology Hardware \& Equipment sector, target capital, equity offered and year dummies. Errors are clustered at the industry level as in Hornuf et al. (2018). It also accounts for investor preference in specific industry groups as evidence suggest in Johan and Zhang (2021).

\footnotetext{
4 Table 11 in the appendix provides results based on Marginal Effects at the Means (MEM), changes between maximum and minimum values and changes in terms of standard deviations. The main results reported in Sect. 4 remain unchanged.

${ }^{5}$ See Cumming et al., (2019a, 2019b, 2019c) for an interesting discussion of these issues and their implications.
} 


\section{Empirical results}

This section first reports basic descriptive statistics for our sample of 1291 startups over the 2013-2018 period. It then proceeds to present and discuss the key results of our multivariate empirical analysis on the effect of founder team characteristics on the probability of startups choosing one of the Big 3 UK platforms to launch their initial campaigns.

\subsection{Descriptive statistics}

Table 1 reports the definitions of the variables employed in the empirical analysis.

The key variables of interest include four measures of team heterogeneity: team size, tenure, nationality and age heterogeneity following Chemmanur and Paeglis (2005). Note that team size is a continuous variables, which encompasses the Greenberg and Mollick (2018) distinction between solo ventures (team size $=1$ ) and founder teams (team size $>1$ ). Other variables of interest include experienced team (dummy equal to 1 for above median founder team age) and advanced degree. ${ }^{6}$

Table 2 presents the basic descriptive statistics for all variables.

The average founder team size in our sample has 2.34 members. Crowdcube campaigns account for $60 \%$ of our sample, Seedrs for $29 \%$, and SyndicateRoom for $12 \%$. The average team tenure and age heterogeneity are 1.2 and 9.2 years, respectively. Around $28 \%$ of campaigns are conducted by firms that include at least one non-UK founding team member. By construction, half our sample is formed by an experienced team (i.e. average team age exceeds the sample median team age of 43). Only $7 \%$ of firms have at least one founder team member that holds a Doctor or Professor title. The average pre-money valuation of startups in our sample is $£ 3.17 \mathrm{~m}$ and $79 \%$ of them are less than 5 years old (startups). The sample firms are geographically concentrated with $46 \%$ located in London. Some $48 \%$ of firms operate in the Technology sector and are mainly undiversified (i.e. with a strong focus on a single sector). The average target capital is $£ 0.32 \mathrm{~m}$ and the average equity offered is around $14 \%$.

Before conducting a multivariate analysis, we test for the presence of multicollinearity among the variables by reporting the values of their correlation coefficients in Table 3 .

The table shows that there are no high pairwise correlations between the variables, except for the case of correlations between team characteristics which is to be expected. For this reason and to avoid concerns of high correlations, we analyse team characteristics separately in the following sections.

Given the central importance of platforms within our analysis, we focus on the differences across the 3 platforms by performing multiple-sample multivariate tests on means under the null of equal means for all platforms. This yields a Wald chi-squared statistic. The results are reported in Table 4.

The test statistic overwhelmingly suggests statistically significant differences across platforms both in terms of team characteristics and firm-level variables. These results justify our focus on platforms and are consistent with existing studies that document platform effects in ECF (Rossi et al., 2019). There are two exceptions. The results indicate no significant differences across platforms in terms of diversification and a focus on the Technology sector.

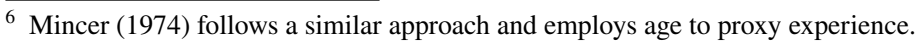




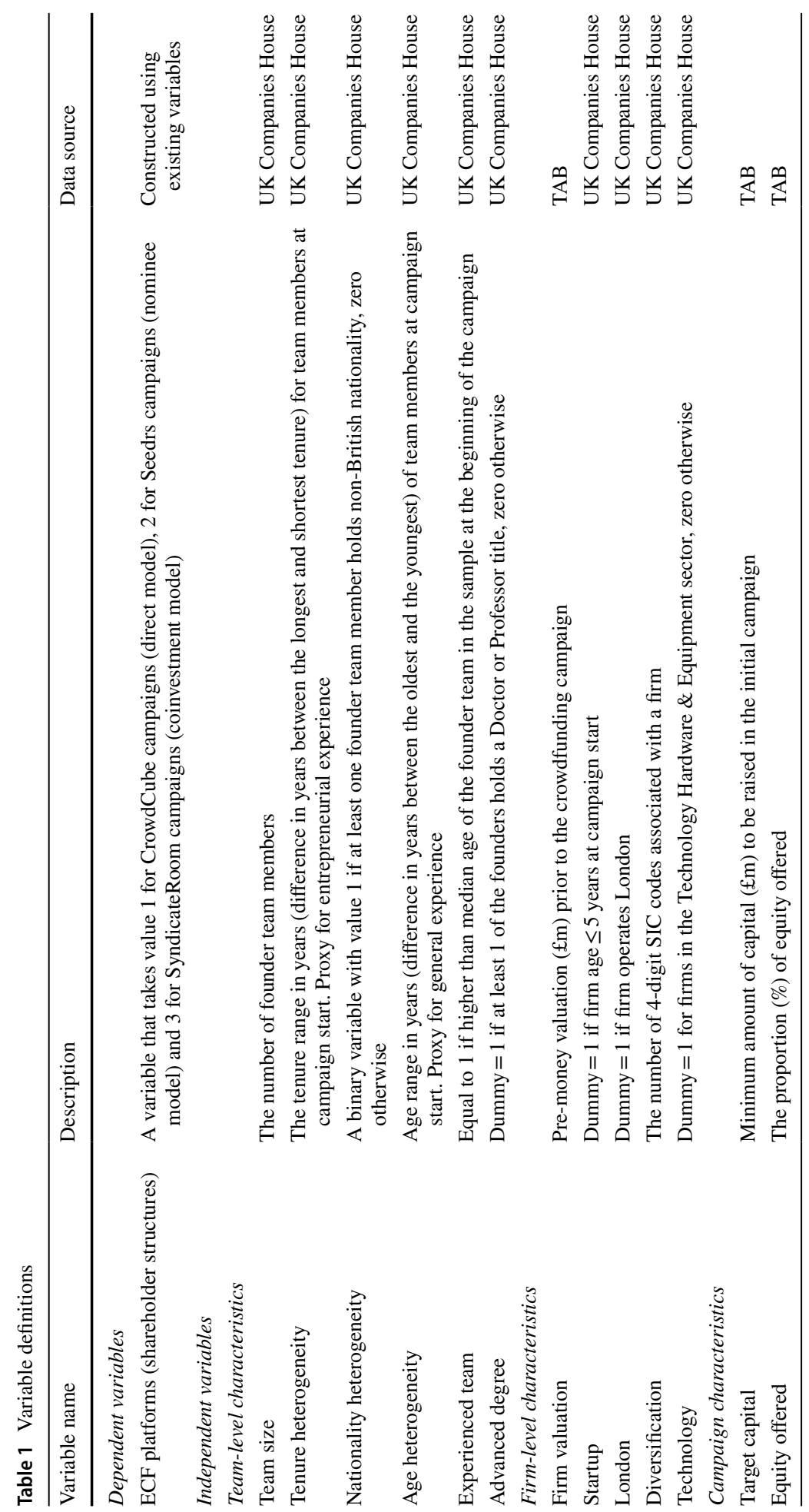


Table 2 Descriptive statistics

\begin{tabular}{lcccccccc}
\hline Variable & N & Mean & SD & P25 & Median & P75 & Min & Max \\
\hline Platform choice & & & & & & & & \\
ECF platforms & 1291 & 1.52 & 0.69 & 1 & 1 & 2 & 1 & 3 \\
Crowdcube & 1291 & 0.60 & 0.49 & 0 & 1 & 1 & 0 & 1 \\
Seedrs & 1291 & 0.29 & 0.45 & 0 & 0 & 1 & 0 & 1 \\
SyndicateRoom & 1291 & 0.12 & 0.32 & 0 & 0 & 0 & 0 & 1 \\
Team characteristics & & & & & & & & \\
Team size & 1288 & 2.34 & 1.42 & 1 & 2 & 3 & 1 & 11 \\
Tenure heterogeneity & 1288 & 1.20 & 2.46 & 0 & 0 & 1.36 & 0 & 26.42 \\
Nationality heterogeneity & 1288 & 0.28 & 0.45 & 0 & 0 & 1 & 0 & 1 \\
Age heterogeneity & 1288 & 9.19 & 11.49 & 0 & 3.8 & 15.09 & 0 & 64.88 \\
Experienced team & 1288 & 0.49 & 0.50 & 0 & 0 & 1 & 0 & 1 \\
Advanced degree & 1288 & 0.07 & 0.26 & 0 & 0 & 0 & 0 & 1 \\
Firm-level characteristics & & & & & & & & \\
Firm valuation & 1172 & 3.17 & 5.52 & 0.72 & 1.35 & 3.37 & 0.08 & 68.6 \\
Startup & 1291 & 0.79 & 0.41 & 1 & 1 & 1 & 0 & 1 \\
London & 1291 & 0.46 & 0.50 & 0 & 0 & 1 & 0 & 1 \\
Diversification & 1277 & 1.18 & 0.52 & 1 & 1 & 1 & 1 & 4 \\
Technology & 1289 & 0.48 & 0.50 & 0 & 0 & 1 & 0 & 1 \\
Campaign characteristics & & & & & & & & \\
Target capital & 1291 & 0.32 & 0.39 & 0.10 & 0.20 & 0.40 & 0.00 & 6.00 \\
Equity offered & 1232 & 14.12 & 8.26 & 8.94 & 12.5 & 18.42 & 0.08 & 67.75 \\
\hline
\end{tabular}

This table reports the number of observations along with mean, minimum, maximum, standard deviation, 25th, 50th and 75th percentiles of variables employed in this study. The sample involves initial ECF offerings conducted on Crowdcube, Seedrs and SyndicateRoom and spans the period from January 2013 to December 2018

\subsection{Multivariate analysis}

Tables 5 to 10 shows the average marginal effects (AME) from multinomial probit regressions predicting the choice of a platform for launching an ECF campaign) by founder teams in terms of size and heterogeneity. In each table, Model 1 excludes the control variables, Model 2 includes the control variables, and Model 3 includes the control variables plus year fixed effects. Looking at the model fit statistics, it is clear from all the Tables 5 to 10 that both the log likelihood and $\mathrm{R}^{2}$ increase as we move from Models 1 to 3 , indicating a better fitting model. In other words, Model 3 demonstrates increased explanatory power over Model 1 in all cases. Both Models 2 and 3 have a lower Akaike Information Criterion (AIC) and Bayesian information criterion (BIC) compared to Model 1, suggesting that fit is improved in both models after including control variables while statistical significance of our key independent variables remains largely unchanged. 


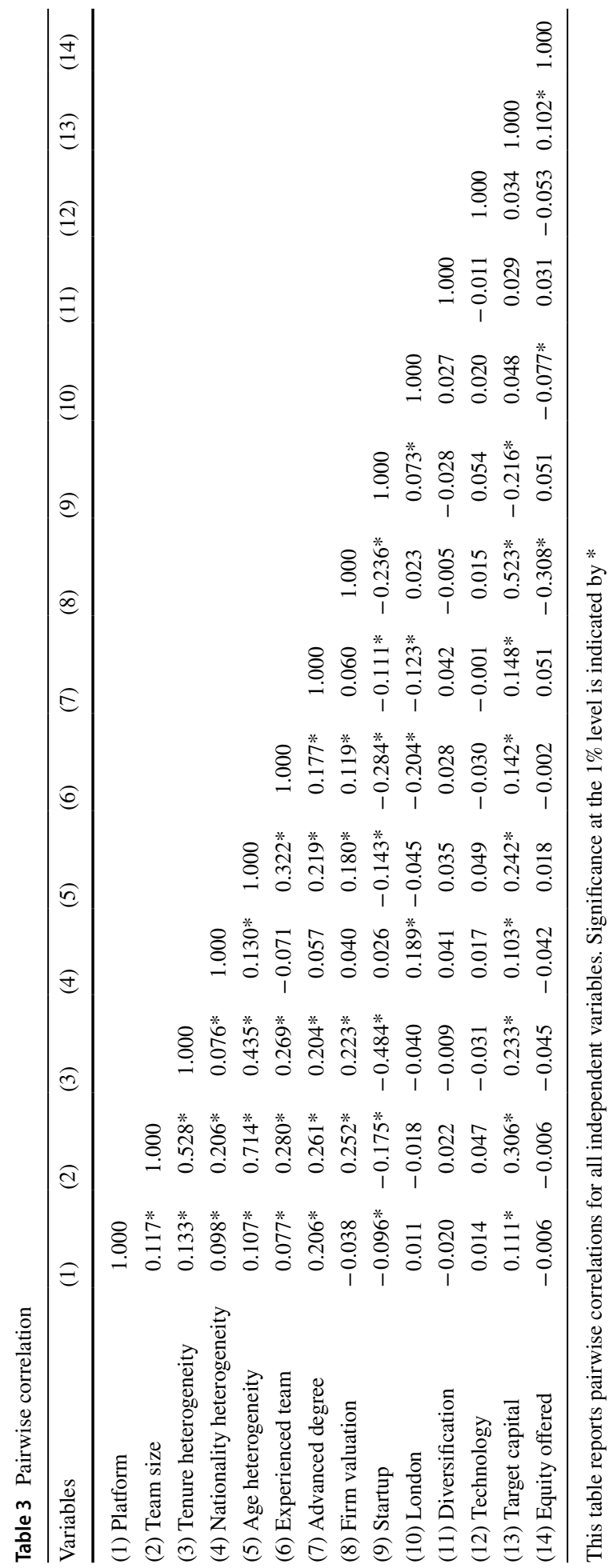


Table 4 Descriptive statistics at platform level

\begin{tabular}{|c|c|c|c|c|c|c|c|}
\hline & \multicolumn{2}{|c|}{ Crowdcube } & \multicolumn{2}{|l|}{ Seedrs } & \multicolumn{2}{|c|}{ SyndicateRoom } & \multirow{2}{*}{$\begin{array}{l}\text { (Wald } \\
\text { chi-squared } \\
\text { statistic) }\end{array}$} \\
\hline & Mean & SD & Mean & SD & Mean & $\mathrm{SD}$ & \\
\hline \multicolumn{8}{|l|}{ Team characteristics } \\
\hline Team size & 2.331 & 1.413 & 1.984 & 1.151 & 3.282 & 1.603 & $83.63 * * *$ \\
\hline Tenure heterogeneity & 1.100 & 2.151 & 0.808 & 2.069 & 2.657 & 3.921 & $30.43 * * *$ \\
\hline Nationality heterogeneity & 0.249 & 0.433 & 0.279 & 0.449 & 0.403 & 0.492 & $12.71 * * *$ \\
\hline Age heterogeneity & 8.957 & 11.226 & 7.202 & 10.602 & 15.335 & 12.906 & $46.50 * * *$ \\
\hline Experienced team & 0.501 & 0.500 & 0.401 & 0.491 & 0.738 & 0.441 & $58.24 * * *$ \\
\hline Advanced degree & 0.052 & 0.222 & 0.038 & 0.191 & 0.282 & 0.451 & $40.61 * * *$ \\
\hline \multicolumn{8}{|l|}{ Firm-level characteristics } \\
\hline Firm valuation & 3.499 & 6.425 & 2.477 & 4.275 & 3.433 & 3.306 & $11.72 * * *$ \\
\hline Startup & 0.794 & 0.405 & 0.847 & 0.361 & 0.591 & 0.493 & $33.22 * * *$ \\
\hline London & 0.430 & 0.495 & 0.548 & 0.498 & 0.356 & 0.480 & $21.41 * * *$ \\
\hline Diversification & 1.190 & 0.533 & 1.144 & 0.474 & 1.184 & 0.562 & 2.11 \\
\hline Technology & 0.488 & 0.500 & 0.454 & 0.499 & 0.544 & 0.500 & 3.49 \\
\hline \multicolumn{8}{|l|}{ Campaign characteristics } \\
\hline Target capital & 0.313 & 0.345 & 0.258 & 0.444 & 0.537 & 0.434 & $44.81 * * *$ \\
\hline Equity offered & 14.872 & 7.587 & 11.310 & 6.885 & 17.469 & 11.759 & $76.91 * * *$ \\
\hline
\end{tabular}

This table shows descriptive statistics across equity crowdfunding platforms. We use the "mvtest means" test available on Stata 16.1 to perform a multiple-sample multivariate test on means under the null of equal means for each platform

$* * *$ Significance at the $1 \%$ level

Table 5 presents the results using a continuous variable to measure team size.

The results reveal that the average marginal effect (AME) on founder team size is significantly positive for SyndicateRoom but significantly negative for Seedrs, both at the $1 \%$ level. The positive value implies that larger teams are more likely to choose SyndicateRoom and this supports H1A. By contrast, team size is inversely associated with the probability of choosing the (Seedrs) nominee structure in line with H1B. The implication is that smaller teams are more likely to launch their campaigns in Seedrs. Finally, the Crowdcube AME for team size is statistically insignificant indicating that team size does not matter for choosing Crowdcube (see Fig. 1 also). Instead, Table 5 indicates that firm valuation, equity offered and being a startup all have statistically positive impacts on the choice of Crowdcube.

An alternative way of exploring the relationship between team size and platform choice is by computing and plotting predicted probabilities as team size increases. These relationships are depicted in Fig. 1. 


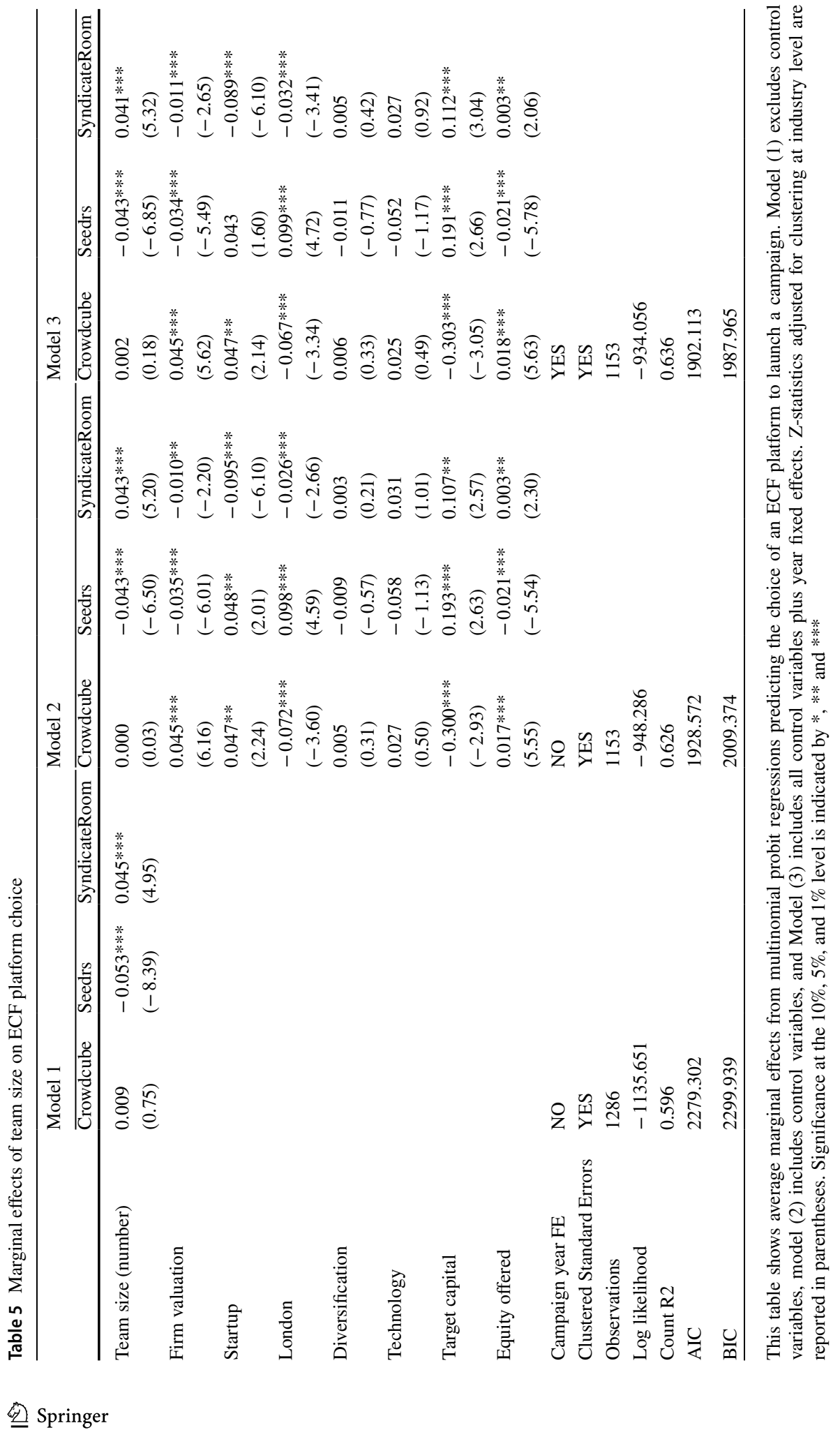




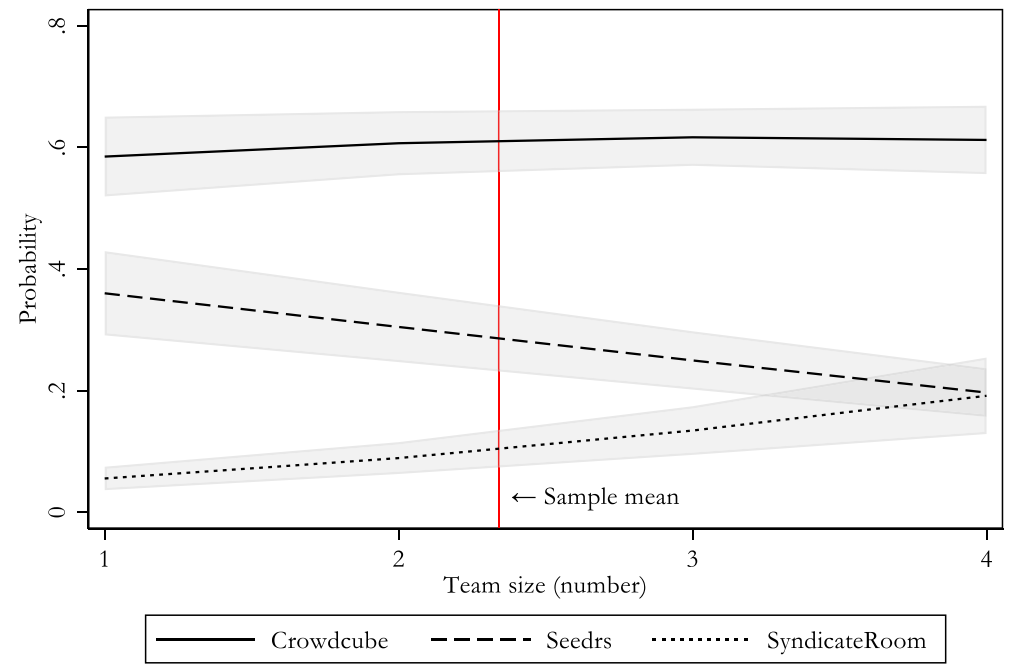

Fig. 1 Analysis of the predicted probabilities of ECF platform choice by team size This figure shows predicted probabilities of ECF platform choice across team sizes (mean +3 standard deviations) with $95 \%$ confidence intervals based on the estimated full Model (3) in Table 5

Figure 1 shows that, for the mean team size, the probability of choosing Crowdcube is just under $60 \%$ but its slope is close to zero, consistent with an insignificant AME in Table 5. By contrast, the probability of choosing Seedrs for the mean team size is around $30 \%$, and that for SyndicateRoom is only 10\%. The probability of choosing Seedrs drops substantially as team size increases, portraying graphically this negative relationship presented in Table 5. Conversely, the probability of choosing SyndicateRoom increases monotonically suggesting a clear and strong positive relationship. These two results lend further support to Hypotheses $1 \mathrm{~A}$ and $1 \mathrm{~B}$.

The separate results for tenure and nationality heterogeneity are summarized in Tables 6 and 7 , respectively.

The AME coefficients capturing the team tenure and nationality heterogeneity are all positive and significant at the $1 \%$ level for the SyndicateRoom co-investment shareholder structure across all models in both Tables 6 and 7. This supports H2. The implication is that heterogeneous teams are more likely to conduct their campaigns on a platform that has a business angel as lead investor. This is consistent with the Jin et al. (2017)'s meta-study in which diversity is positively associated with venture performance. By contrast, the team tenure and nationality heterogeneity coefficients are statistically insignificant for both Crowdcube and Seedrs but those for firm valuation and equity offered are once again (as in Table 5) significantly positive for Crowdcube only.

We also examine the relation between the predicted probability of choosing a platform for specific values of founder team heterogeneity. This is illustrated in Fig. 2 where the vertical (horizontal) axis reports predicted platform probabilities (heterogeneity values).

Figure 2 shows an upward slope for SyndicateRoom (starting at around 0.15) reflecting a positive relation between tenure heterogeneity and the probability of choosing the coinvestment model. By contrast, the relationship for Seedrs exhibits a downward slope like that for Crowdcube. Crowdcube slope is roughly flat in line with the insignificant coefficient in Table 6. Seedrs exhibits lower probabilities for the same values of tenure heterogeneity 


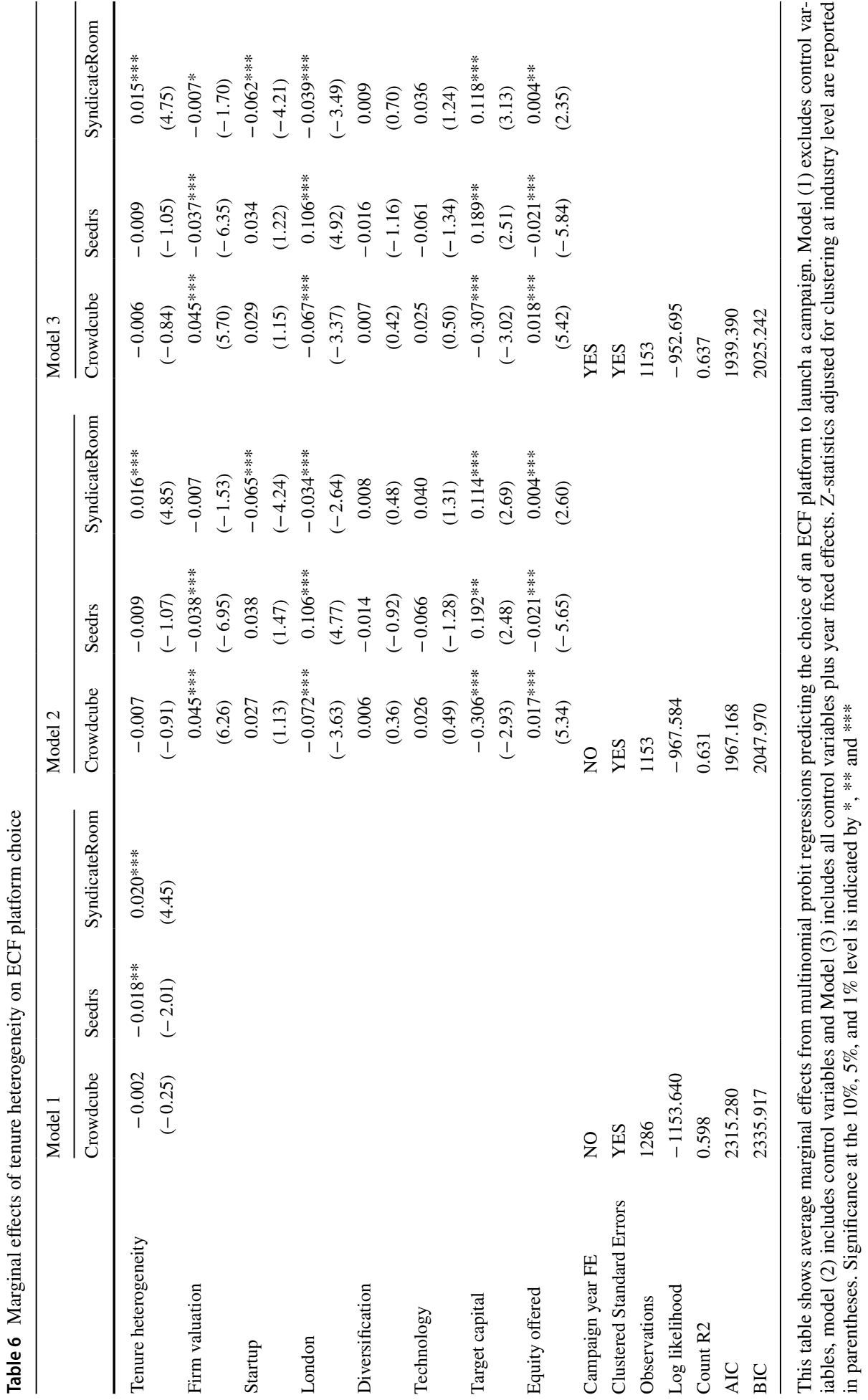




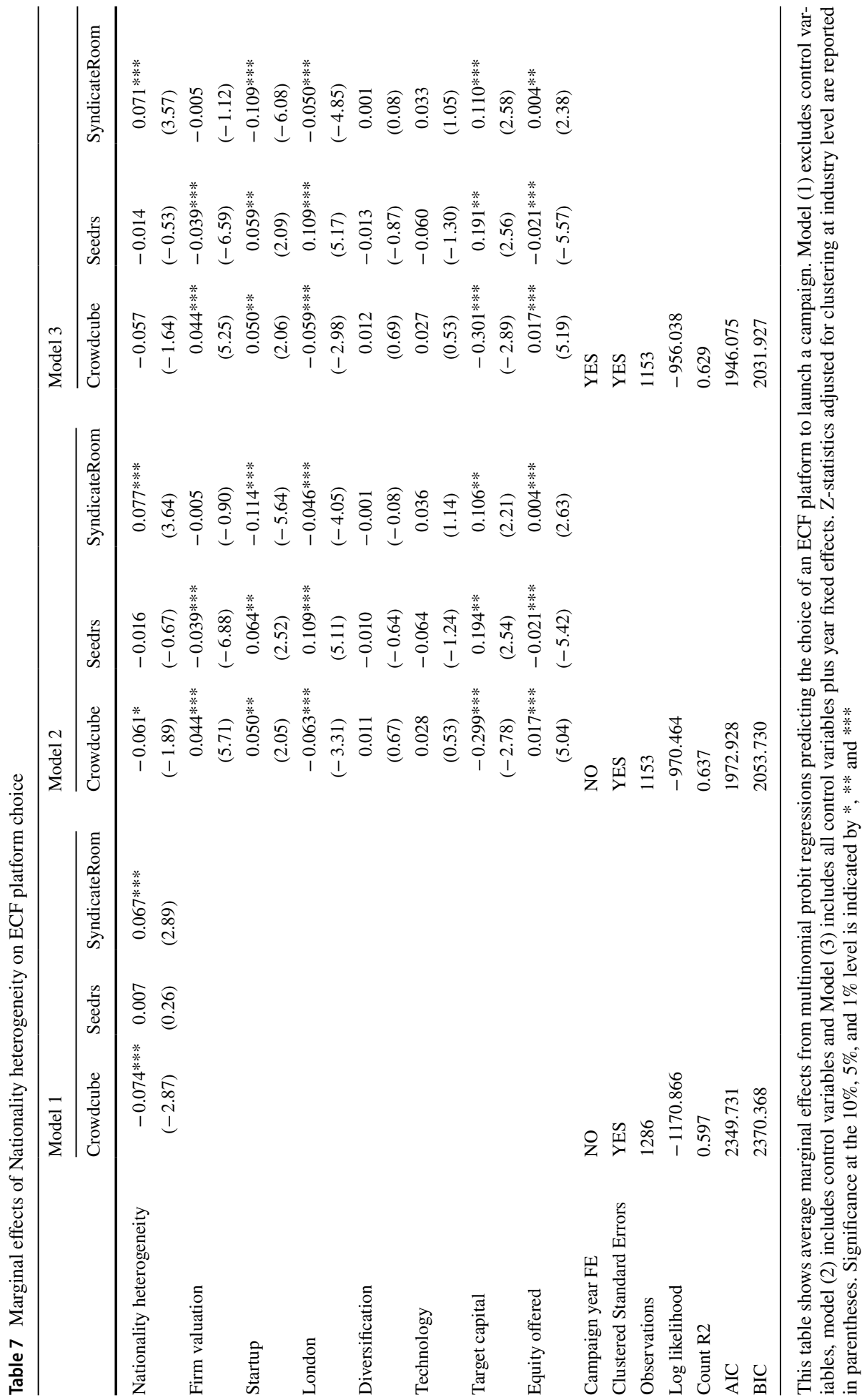




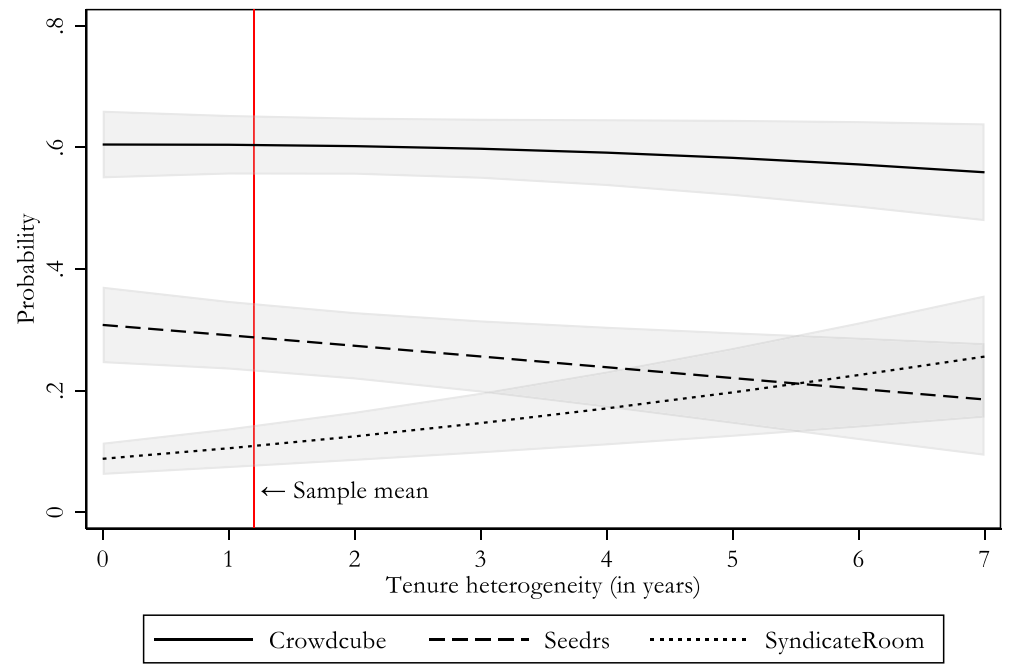

Fig. 2 Analysis of the predicted probabilities of ECF platform choice by tenure heterogeneity This figure shows predicted probabilities of ECF platform choice across different levels of tenure heterogeneity (sample mean +3 standard deviations) with $95 \%$ confidence intervals based on the estimated full Model (3) in Table 6

compared to Crowdcube. It is worth noting that teams with tenure heterogeneity of around 5.5 years have the same predicted probability of choosing either SyndicateRoom or Seedrs.

The results for age heterogeneity are summarized in Table 8 .

The results show that age heterogeneity exhibits a significantly positive AME for the SyndicateRoom platform while yielding corresponding significantly negative AME for the Seedrs platform, both at the $1 \%$ level. One can think of age heterogeneity as reflecting the general experience of the founder team.

Figure 3 depicts the relation between the predicted probability of choosing a platform for specific values of founder team age heterogeneity.

The patterns are quite similar to those in Fig. 1. In line with previous results, Fig. 3 shows an upward slope for SyndicateRoom reflecting a positive relation between team age heterogeneity and the probability of choosing the co-investment model.

Next, we focus on the relation between highly educated and experienced teams and the probability of choosing a specific platform structure to conduct their campaigns. The results are summarized in Tables 9 and 10 for teams for experienced teams and advanced degree, respectively.

The results suggest that experienced and highly educated teams are more likely to conduct their campaigns on the SyndicateRoom platform as their AMEs are positive and significant at the 1\% level in both Tables 9 and 10. This supports our hypothesis H3. The Table 9 results also show that experienced teams are less likely to choose a nominee platform to raise capital but the advanced degree coefficient is insignificant in Model 3 in Table 10.

Our results so far lend support to and complement the findings of existing studies which document platform effects in the ECF market (Rossi et al., 2018). While their focus is on what happens during the campaign, our focus is on the pre-campaign stage decision. Our results may shed more light on digital corporate governance studies as well (Cumming 


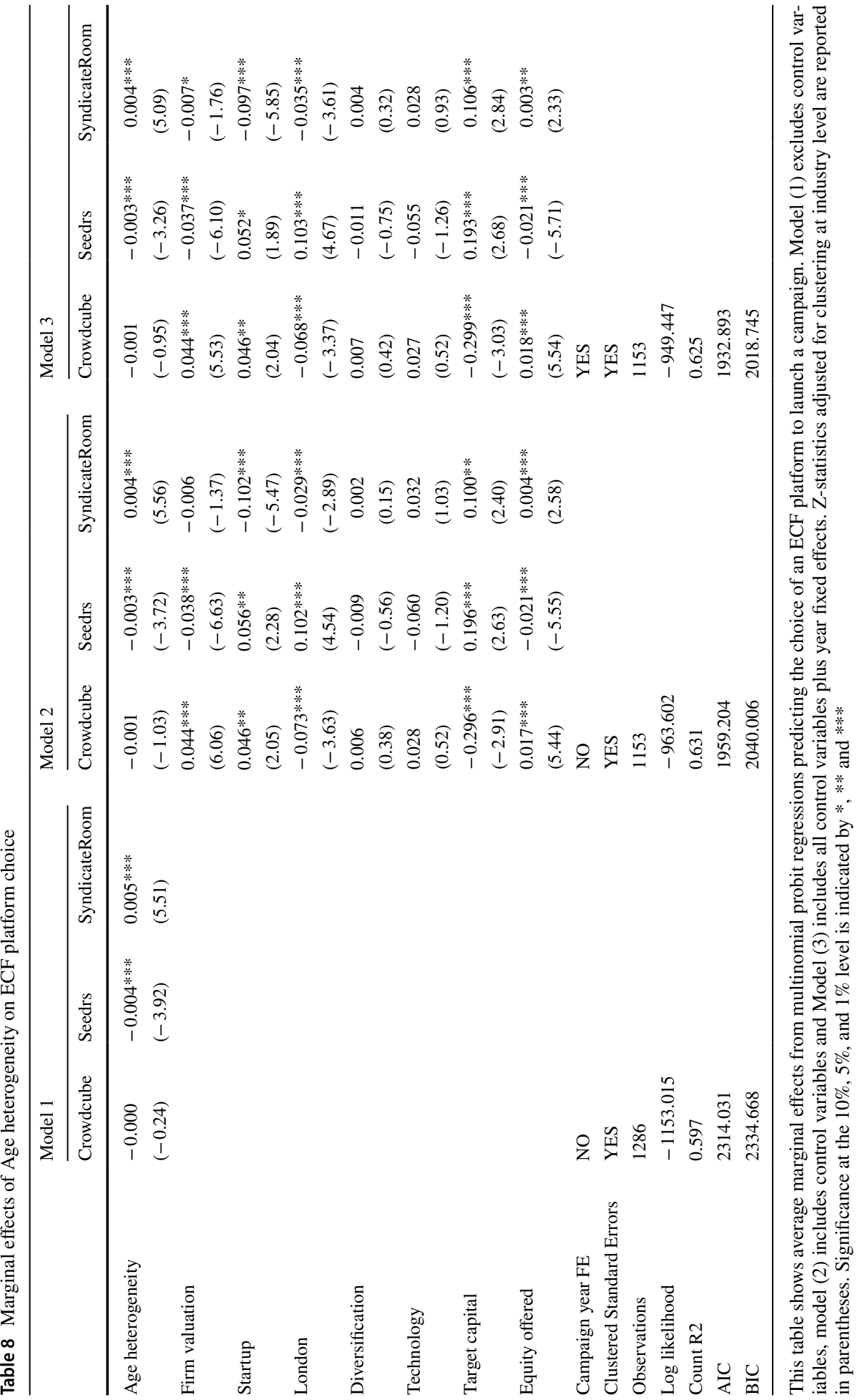




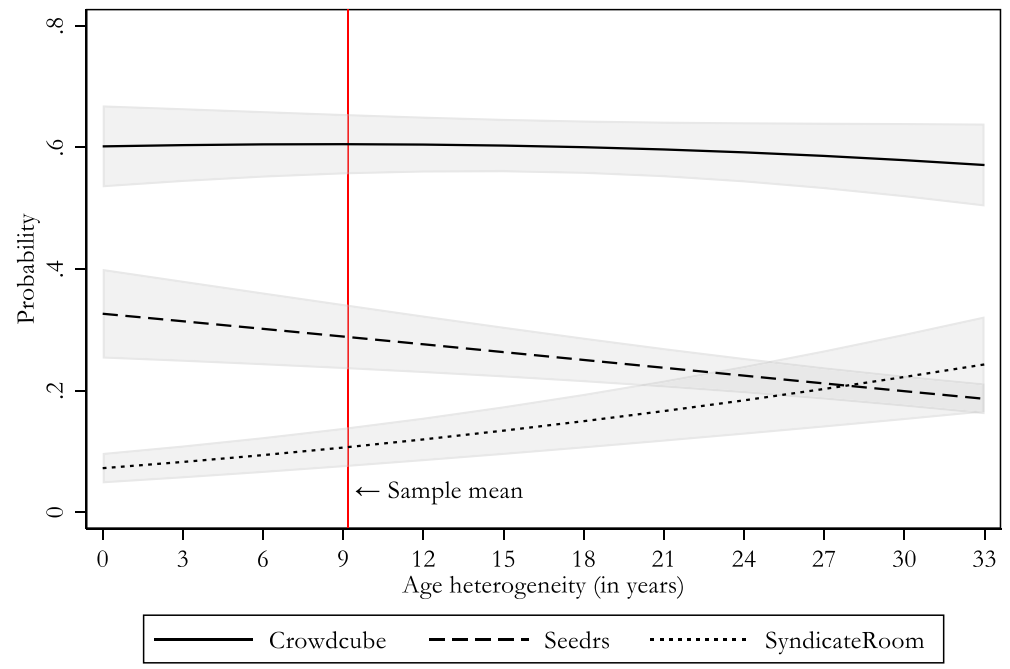

Fig. 3 Analysis of the predicted probabilities of ECF platform choice by age heterogeneity This figure shows predicted probabilities of ECF platform choice across different levels of age heterogeneity $(m e a n+3$ standard deviations) with $95 \%$ confidence intervals based on the estimated full Model (3) in Table 8

et al, 2019b), as shown in the previous section findings where team characteristics matter during the ECF platform choice (and associated shareholder structure choice) stage.

It is worth noting that Crowdcube coefficient is insignificant in most of the cases. Crowdcube offers a dual shareholder structure. It started offering the direct scheme at its inception, it gave another option to entrepreneurs though by offering the nominee in February 2015. Coakley et al. (2021c) focus on the effect of nominee on ECF outcomes in the long and short run at inter and intra platform level. Their findings reveal that nominee offerings are more likely to be successful in the short and long run. Put differently nominee may be an effective signal that may reflect team quality. Given that Crowdcube offers both nominee and direct, this may help explain the insignificant coefficients on Crowdcube. A future intra-platform analysis may shed more light on this.

Our findings reveal that heterogeneous, highly educated and experienced teams are more likely to conduct campaigns on a platform that requires the commitment of professional investor. ${ }^{77} \mathrm{CCAF}$ report that the share of ECF investment by institutional investors increased from just $8 \%$ in 2015 to $25 \%$ in 2016 and to $49 \%$ in 2017 and was around 50\% in 2018. A possible explanation may lie in the positive association between signaller quality and signal effectiveness (Connelly et al, 2011; Spence, 1973). Chemmanur and Paeglis (2005) argue that later stage teams with these characteristics are high quality teams and have a positive effect on IPO outcomes. The commitment of a professional investor may be an effective signal for reducing information asymmetry in ECF (Ralcheva \& Roosenboom, 2016). As a result, heterogeneous teams may be high quality signallers who may choose the co-investment platform to enhance signal quality for their startups. 


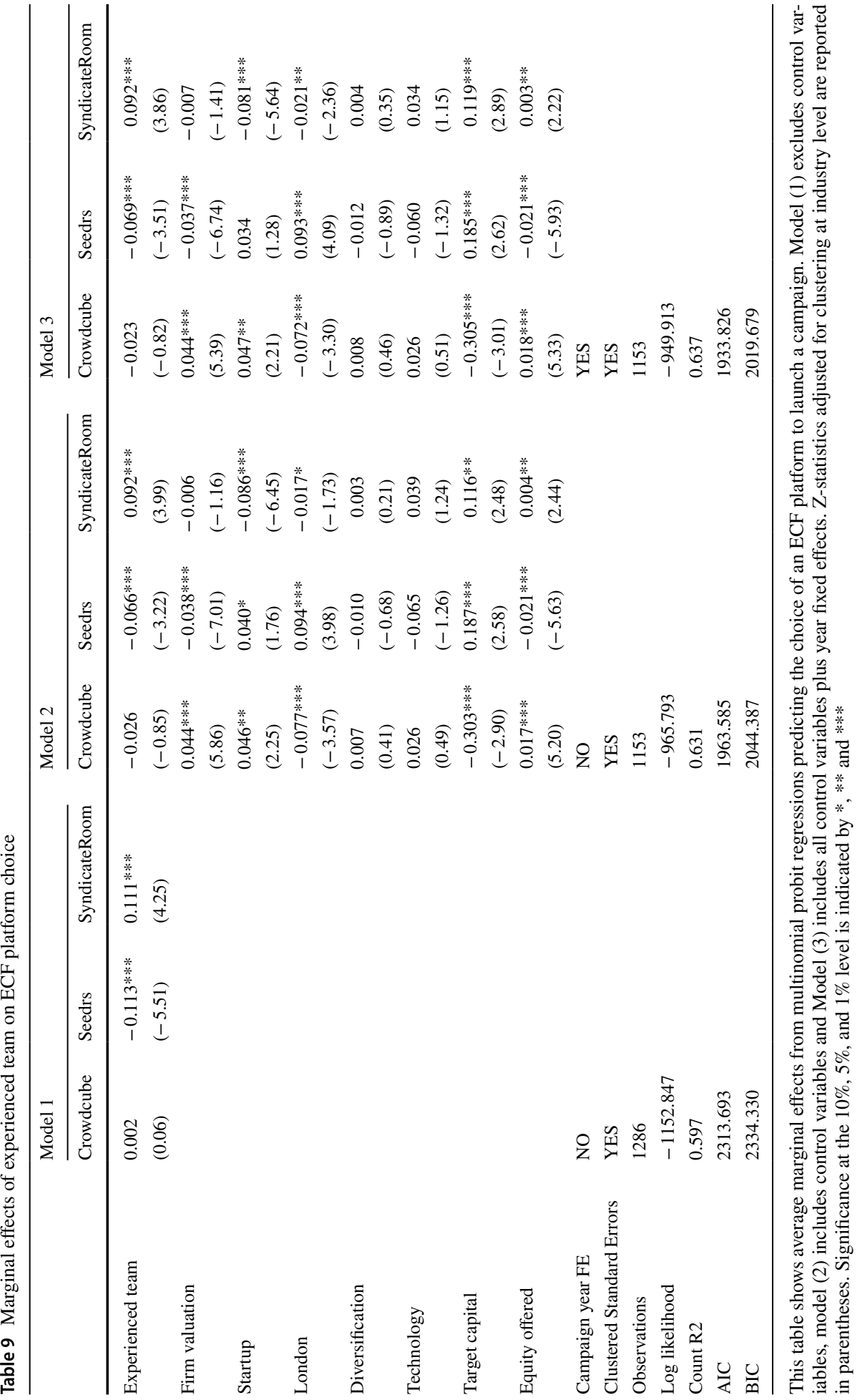




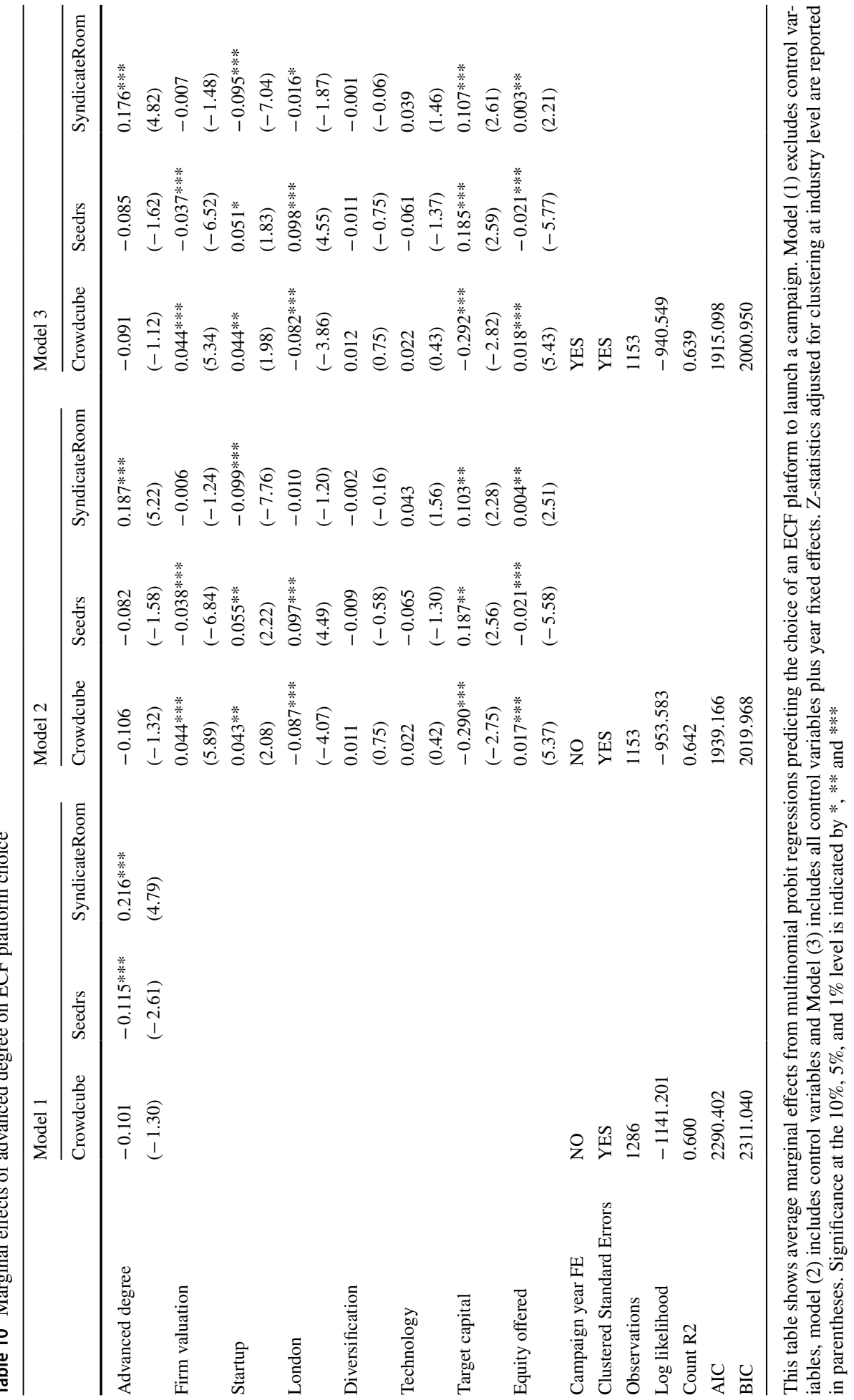




\subsection{Robustness tests}

To address the increase in co-investment in the final years of our sample, we restrict our sample to the 2016-2018 period and the summary results are presented in Table 12 while the corresponding summary results for the full sample period are given in Table 11. They provide further support for our main previous findings: larger and heterogenous firms are more likely to choose the co-investment ECF model to raise outside equity on ECF platforms. This is corroborated by the fact that all of the SyndicateRoom marginal effects in Table 12 are significantly positive at the $1 \%$ level with the exception of nationality heterogeneity.

However, there are now marked differences between the Crowdcube and Seedrs findings for the two samples. Table 11 for the full sample confirms that the marginal effects for Seedrs were largely significantly negative whilst those for Crowdcube were mostly insignificant. Now by contrast, Table 12 reveals that the Crowdcube and Seedrs marginal effects are reversed. They are mostly significantly negative for the Crowdcube platform (excluding nationality heterogeneity) whilst those for Seedrs are now virtually all (excluding team size) insignificant. The implication is that as co-investment has increased, larger and more heterogeneous teams are less likely to choose the Crowdcube platform.

As a final robustness check, Table 13 in the Appendix include results of models including all team characteristics simultaneously. The main results remain largely similar.

\section{Conclusions and discussion}

This study extends the existing ECF literature by examining strategic entrepreneurial choice among competing platform or shareholder structures. It employs firm and campaign data from Crowdcube, Seedrs and SyndicateRoom for the period from January 2012 to December 2018. The multinomial probit results suggest that larger and heterogenous founder teams are more likely to conduct campaigns on a platform that employs the coinvestment model. They lend support to the findings of Cumming et al. (2019b) and Rossi et al. (2019) in which platform shareholder structure matters in ECF. They are also in line with entrepreneurial studies in which founder team is possibly the most important factor when BA or VC funds choose to invest in a firm (Van Osnabrugge, 2000; Sudek, 2006; Gompers et al., 2020).

The theoretical implication of our study is that founder team characteristics matter for platform selection. The main equity crowdfunding platforms in the UK are Crowdcube, Seedrs, Syndicate Room. Each has its individual characteristics including governance structures and campaign support. One of the main aspects to consider from a founder team perspective is whether it will want to use a platform that allows crowdfunding investors to hold shares directly or through a nominee structure. We try to shed light on this issue for the first time through a detailed empirical analysis of the ECF UK market, as the decision to launch a campaign on a specific platform will therefore have potential short- and long-term implications for the startup. As for practical implications, our study may help platforms improve their due diligence process. Due diligence plays a very important role for a sustainable crowdfunding market (Cumming et al, 2019a). In other words, our findings may help platform filter out startups which are less likely to receive investments from professional investors. The latter account for half the investment in the UK ECF market (Zhang et al, 2018) and they exchange information with inexperienced investors. This 
improves the overall efficiency of the ECF market (Wang et al, 2019) and may help create a sustainable and flourishing ECF market.

Although this paper presents the first attempt empirically to study the implications of human capital on choosing a crowdfunding platform in the UK context, some of its limitations offer the opportunity for further research. In the current paper, we only observe firms matched with ECF platforms, but we have no information about startups which are rejected by the platforms. Analysis of whether and how platforms and human capital interact during the pre- and post-campaign process will be useful for a more in-depth analysis in a context of a diverse ecosystem of ECF platforms and interplay among them. In addition, another direction for future study, could be to link market timing and founder characteristics in ECF. Cerpentier et al. (2021) find that ECF firms set higher targets and as a result they raise more capital in hot markets compared to their counterparts in cold markets. Founders choose specific shareholder structure to signal quality thus their decisions may differ between hot and cold markets. Future research may shed more light on this.

\section{Appendix}

See Tables 11, 12, 13. 
Table 11 Summary of key marginal effects for regression models for the full sample (2013-2018)

\begin{tabular}{|c|c|c|c|}
\hline & Crowdcube & Seedrs & SyndicateRoom \\
\hline \multicolumn{4}{|l|}{ Team Size (Table 5) } \\
\hline Change by 1 & -0.003 & $-0.043^{* * *}$ & $0.046 * * *$ \\
\hline AME & 0.002 & $-0.043^{* * *}$ & $0.041 * * *$ \\
\hline MEM & 0.006 & $-0.048^{* * *}$ & $0.042 * * *$ \\
\hline Change over range $(\operatorname{Min} \rightarrow$ Max $)$ & $-0.310 * * *$ & $-0.341^{* * *}$ & $0.652 * * *$ \\
\hline Change by the regressor's standard deviation & -0.007 & $-0.061 * * *$ & $0.068 * * *$ \\
\hline \multicolumn{4}{|l|}{ Tenure heterogeneity (Table 6) } \\
\hline Change by 1 & -0.007 & -0.009 & $0.016^{* * *}$ \\
\hline AME & -0.006 & -0.009 & $0.015 * * *$ \\
\hline MEM & -0.006 & -0.009 & $0.015^{* * *}$ \\
\hline Change over range $(\operatorname{Min} \rightarrow$ Max $)$ & $-0.398 * * *$ & $-0.263^{* * *}$ & $0.660 * * *$ \\
\hline Change by the regressor's standard deviation & -0.019 & -0.022 & $0.041 * * *$ \\
\hline \multicolumn{4}{|l|}{ Nationality heterogeneity (Table 7) } \\
\hline Change from 0 to 1 & $-0.061^{*}$ & -0.017 & $0.078 * * *$ \\
\hline AME & -0.057 & -0.014 & $0.071 * * *$ \\
\hline MEM & -0.057 & -0.015 & $0.072 * * *$ \\
\hline \multicolumn{4}{|l|}{ Age heterogeneity (Table 8) } \\
\hline Change by 1 & -0.001 & $-0.003 * * *$ & $0.004 * * *$ \\
\hline AME & -0.001 & $-0.003 * * *$ & $0.004 * * *$ \\
\hline MEM & -0.001 & $-0.003 * * *$ & $0.004 * * *$ \\
\hline Change over range $(\operatorname{Min} \rightarrow$ Max $)$ & $-0.164 * *$ & $-0.182 * * *$ & $0.346^{* * *}$ \\
\hline Change by the regressor's standard deviation & -0.016 & $-0.030^{* * *}$ & $0.046 * * *$ \\
\hline \multicolumn{4}{|l|}{ Experienced team (Table 9) } \\
\hline Change from 0 to 1 & -0.022 & $-0.071 * * *$ & $0.093 * * *$ \\
\hline AME & -0.023 & $-0.069 * * *$ & $0.092 * * *$ \\
\hline MEM & -0.018 & $-0.075^{* * *}$ & $0.093 * * *$ \\
\hline \multicolumn{4}{|l|}{ Advanced degree (Table 10) } \\
\hline Change from 0 to 1 & $-0.152 *$ & $-0.111^{* * *}$ & $0.263 * * *$ \\
\hline AME & -0.091 & -0.085 & $0.176^{* * *}$ \\
\hline MEM & -0.089 & $-0.093^{*}$ & $0.182 * * *$ \\
\hline
\end{tabular}

Average marginal effects (AME) are computed by averaging over the sample (i.e. changes are averaged across observed values). Marginal effects at the mean (MEM) are computed based on sample means of independent variables. Significance at the $10 \%, 5 \%$, and $1 \%$ level is indicated by *, ** and *** 
Table 12 Summary of key marginal effects for regression models for the restricted sample (2016-2018)

\begin{tabular}{|c|c|c|c|}
\hline & Crowdcube & Seedrs & SyndicateRoom \\
\hline \multicolumn{4}{|l|}{ Team Size (Table 5) } \\
\hline Change by 1 & -0.022 & $-0.022 * *$ & $0.045 * * *$ \\
\hline AME & -0.019 & $-0.021^{*}$ & $0.041 * * *$ \\
\hline MEM & -0.020 & $-0.023 *$ & $0.042 * * *$ \\
\hline Change over range $($ Min $\rightarrow$ Max $)$ & $-0.370 * * *$ & $-0.244 * * *$ & $0.614 * * *$ \\
\hline Change by the regressor's standard deviation & $-0.034 *$ & $-0.033 * *$ & $0.067 * * *$ \\
\hline \multicolumn{4}{|l|}{ Tenure heterogeneity (Table 6) } \\
\hline Change by 1 & $-0.016^{* *}$ & -0.000 & $0.016^{* * *}$ \\
\hline AME & $-0.015^{* *}$ & -0.000 & $0.016 * * *$ \\
\hline MEM & $-0.016^{* *}$ & -0.000 & $0.016 * * *$ \\
\hline Change over range $($ Min $\rightarrow$ Max $)$ & $-0.469 * * *$ & $-0.152 *$ & $0.620 * * *$ \\
\hline Change by the regressor's standard deviation & $-0.046^{* *}$ & -0.003 & $0.049 * * *$ \\
\hline \multicolumn{4}{|l|}{ Nationality heterogeneity (Table 7) } \\
\hline Change from 0 to 1 & $-0.067 *$ & 0.026 & $0.041 *$ \\
\hline AME & $-0.065^{*}$ & 0.026 & $0.040 *$ \\
\hline MEM & $-0.070^{*}$ & 0.028 & $0.042 *$ \\
\hline \multicolumn{4}{|l|}{ Age heterogeneity (Table 8) } \\
\hline Change by 1 & $-0.004 * * *$ & 0.000 & $0.004 * * *$ \\
\hline AME & $-0.004 * * *$ & 0.000 & $0.004 * * *$ \\
\hline MEM & $-0.005 * * *$ & 0.001 & $0.004 * * *$ \\
\hline Change over range $(\operatorname{Min} \rightarrow$ Max $)$ & $-0.233 * * *$ & -0.003 & $0.236 * * *$ \\
\hline Change by the regressor's standard deviation & $-0.052 * * *$ & 0.003 & $0.049 * * *$ \\
\hline \multicolumn{4}{|l|}{ Experienced team (Table 9) } \\
\hline Change from 0 to 1 & $-0.109 * * *$ & -0.012 & $0.122 * * *$ \\
\hline AME & $-0.109 * * *$ & -0.012 & $0.121 * * *$ \\
\hline MEM & $-0.115^{* * *}$ & -0.010 & $0.125 * * *$ \\
\hline \multicolumn{4}{|l|}{ Advanced degree (Table 10) } \\
\hline Change from 0 to 1 & $-0.149 * *$ & -0.070 & $0.218 * * *$ \\
\hline AME & -0.112 & -0.049 & $0.161 * * *$ \\
\hline MEM & -0.120 & -0.052 & $0.172 * * *$ \\
\hline
\end{tabular}

Average marginal effects (AME) are computed by averaging over the sample (i.e.changes are averaged across observed values). Marginal effects at the mean (MEM) are computed based on sample means of independent variables. Significance at the $10 \%, 5 \%$, and $1 \%$ level is indicated by $*, * *$ and $* * *$ 


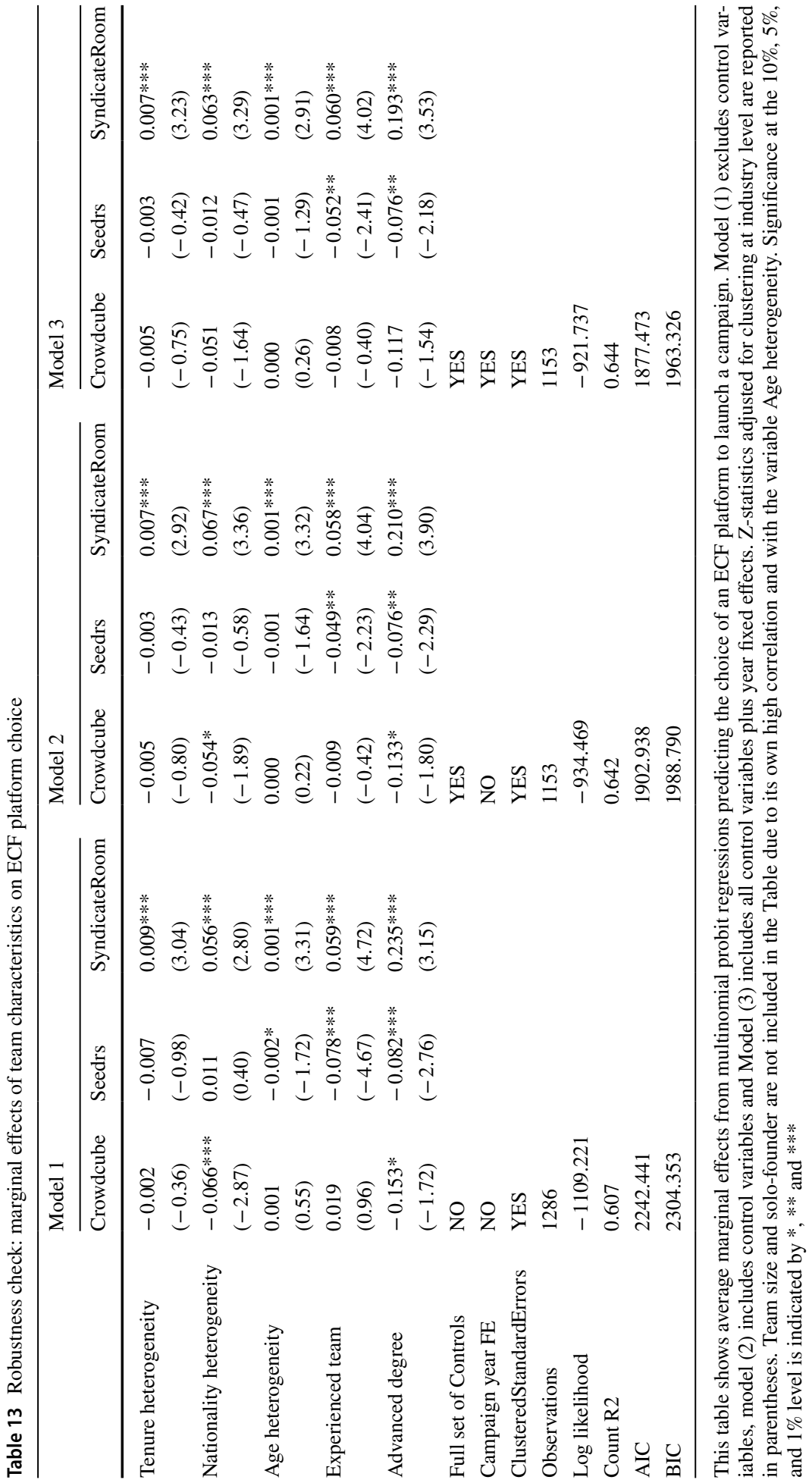


Open Access This article is licensed under a Creative Commons Attribution 4.0 International License, which permits use, sharing, adaptation, distribution and reproduction in any medium or format, as long as you give appropriate credit to the original author(s) and the source, provide a link to the Creative Commons licence, and indicate if changes were made. The images or other third party material in this article are included in the article's Creative Commons licence, unless indicated otherwise in a credit line to the material. If material is not included in the article's Creative Commons licence and your intended use is not permitted by statutory regulation or exceeds the permitted use, you will need to obtain permission directly from the copyright holder. To view a copy of this licence, visit http://creativecommons.org/licenses/by/4.0/.

\section{References}

Agarwal, R., Braguinksy, S., \& Ohyama, A. (2020). Centers of gravity: The effects of shared leadership and stability in top management teams on firm growth and industry evolution. Strategic Management Journal, 41, 467-498.

Agrawal, A., Catalini, C., \& Goldfarb, A. (2016). Are syndicates the killer app of equity crowdfunding? Calif Management Rev, 58, 111-124.

Ahlers, G. K., Cumming, D., Gunther, C., \& Schweizer, D. (2015). Signaling in equity crowdfunding. Entrepreneurship Theory and Practice, 39, 955-980.

Bantel, K. A., \& Jackson, S. E. (1989). Top management and innovations in banking: Does the composition of the top team make a difference? Strategic Management Journal, 10, 107-124.

Barbi, M., \& Mattioli, S. (2019). Human capital, investor trust and equity crowdfunding. Research in International Business and Finance, 49, 1-12.

Buttice, V., \& Vismara, S. (2021). Inclusive digital finance: The industry of equity crowdfunding. Journal of Technology Transfer. https://doi.org/10.1007/s10961-021-09875-0

Buttice, V., Di Pietro, F., \& Tenca, F. (2021). They Do Not Look Alike: What Kind of private investors do equity crowdfunded firms attract? Journal of Technology Transfer. https://doi.org/10.1007/ s10961-021-09895-w

Cameron, A. C., \& Trivedi, P. K. (2005). Microeconometrics: Methods and applications. Cambridge University Press.

Cassar, G. (2004). The Önancing of business start-ups. Journal of Business Venturing, 19, 261-283.

Cerpentier, M., Vanacker, T., Paeleman, I., Bringman, I. (2021). Equity crowdfunding, market timing, and firm capital structure. Journal of Technology Transfer. Forthcoming.

Chemmanur, T. J., \& Paeglis, I. (2005). Management quality, certification, and initial public offerings. Journal of Financial Economics, 76, 331-368.

Chrobot-Mason, D., Ruderman, M. N., Weber, T. J., \& Ernst, C. (2009). The challenge of leading on unstable ground: Triggers that activate social identity fault lines. Human Relations, 62, 1763-1794.

Coakley, J., Cumming, D., Lazos, A., \& Vismara, S. (2021a). Enfranchising the crowd: Nominee account equity crowdfunding. University of Essex.

Coakley, J., \& Lazos, A. (2021). Recent developments in equity crowdfunding: A review. Review of Corporate Finance, 1, 341-405.

Coakley, J., Lazos, A., \& Linares-Zegarra, J. (2021b). Seasoned equity crowdfunded offerings. Journal of Corporate Finance. https://doi.org/10.1016/j.jcorpfin.2020.101880

Coakley, J., Lazos, A., \& Linares-Zegarra, J. M. (2021c). Equity crowdfunding founder teams: Campaign success and venture failure. British Journal of Management. https://doi.org/10.1111/14678551.12494

Connelly, B., Certo, S. V., Ireland, R. D., \& Reutzel, C. (2011). Signaling theory: A review and assessment. Journal of Management, 37, 39-67.

Cooper, A. C., Woo, C. Y., \& Dunkelberg, W. C. (1994). Initial human and Önancial capital as predictors of new venture performance. Journal of Business Venturing, 9, 371-395.

Cumming, D. J., Hornuf, L., Karami, M., \& Schweizer, D. (2020). Disentagling crowdfunding from fraudfunding. eLibrary SSRN

Cumming, D. J., Martinez-Salgueiro, A., Reardon, R., \& Sewaid, A. (2021). COVID-19 Bust, policy response, and rebound: Equity Crowdfunding and P2P vs. Banks. Journal of Technology Transfer. Forthcoming

Cumming, D. J., Johan, S., \& Zhang, Y. (2019a). The role of due diligence in crowdfunding platforms. Journal of Banking \& Finance, 108, 105-661.

Cumming, D. J., Meoli, M., \& Vismara, S. (2019b). Investor's choices between cash and voting rights: Evidence from dual-class equity crowdfunding. Research Policy, 48(8), 103740. 
Cumming, D. J., Vanacker, T., \& Zahra, S. A. (2019c). Equity crowdfunding and governance: Toward an integrative model and research agenda. Academy of Management Perspectives, 35(1), 69-95. Forthcoming.

Eisenhardt, K. M., \& Schoonhoven, C. B. (1990). Organizational growth: Linking founding team, strategy, environment, growth among U.S. semiconductor ventures, 1978-1988. Administrative Science Quarterly, 35, 504-529.

Graham, P. (2006). The eighteen mistakes that kill startups. Available at http://www.paulgraham.com/ startupmistakes.html

Greenberg, J., \& Mollick, E. (2018). Sole Survivors: Solo ventures versus founding teams. Available at SSRN. https://doi.org/10.2139/ssrn.3107898

Hornuf, L., Schmitt, E., \& Stenzhorn, E. (2018). Equity crowdfunding in the Germany and the UK. Follow-up funding and firm failure. Corporate Governance International Review, 26, 331-354.

Hornuf, L., Stenzhorn, E., \& Vintis, T. (2021). Are sustainability-oriented investors different? Evidence from equity Crowdfunding? Journal of Technology Transfer. Forthcoming.

Jin, L., Madison, K., Kraiczy, D., Kellermanns, F. W., \& Crook, T. R. (2017). Entrepreneurial team composition characteristics and new venture performance: A meta-analysis study. Entrepreneurship Theory and Practice, 41, 743-771.

Johan, S, Zhang, Y. (2021). investors' industry preference in equity crowdfunding. Journal of Technology Transfer. Forthcoming.

Junge, L. B., Laursen, I. C., \& Nielsen, K. R. (2021). Choosing crowdfunding: Why do entrepreneurs choose to engagein crowdfunding? Technovation. https://doi.org/10.1016/j.technovation.2021.102385

Kleinert, S., \& Mochkabadi, K. (2021). Gender stereotypes in equity crowdfunding: the effect of gender bias on the interpretation of quality signals. Journal of Technology Transfer. https://doi.org/10.1007/ s10961-021-09892-z

Lazear, E. P. (2005). Entrepreneurship. Journal of Labor Economics, 23, 649-680.

Levine, S. S., Bernard, M., \& Nagel, R. (2017). Strategic intelligence: The cognitive capability to anticipate competitor behavior. Strategic Management Journal, 38(12), 2390-2423.

Li, J., \& Hambrick, D. C. (2005). Factional groups: A new vantage on demographic faultlines, conflict, and disintegration in teams. Academy of Management Journal, 48, 794-813.

Mochkabadi, K., \& Volkmann, C. K. (2020). Equity crowdfunding: A systematic review of the literature. Small Business Economics, 54(1), 75-118.

Murray, A. I. (1989). Top management group heterogeneity and firm performance. Strategic Management Journal, 10, 125-141.

Piva, E., \& Rossi-Lamastra, C. (2018). Human capital signals and entrepreneurs' success in equity crowdfunding. Small Business Economics, 51, 667-686.

Ralcheva, A. \& Roosenboom, P. (2016). On the road to success in equity crowdfunding. eLibrary, SSRN.

Ralcheva, A., \& Roosenboom, P. (2019). Forecasting success in equity crowdfunding. Small Business Economics, 55, 39-56.

Rossi, A., \& Vismara, S. (2018). What do crowdfunding platforms do? A comparison between investmentbased platforms in Europe. Eurasian Business Review, 8, 93-118.

Rossi, A., \& VismaraMeoli, S. M. (2019). Voting rights delivery in investment-based crowdfunding: A cross-platform analysis. Journal of Industrial and Business Economics, 46, 251-281.

Schwienbacher, A. (2013). The entrepreneur's investor choice: The impact on later-stage firm development. Journal of Business Venturing, 28, 528-545.

Signori, A., \& Vismara, S. (2018). Does success bring success? The post-offering lives of equity-crowdfunded firms. Journal of Corporate Finance, 50, 575-591.

SØrensen, J. B., \& Stuart, T. E. (2000). Aging, obsolescence, organizational innovation. Administrative Science Quarterly, 45, 81-112.

Spence, M. (1973). Job market signaling. Quarterly Journal of Economics, 87, 355-374.

Stevenson, R., McMahon S. R., Letwin, C., Ciuchta, M. P. (2021). Entrepreneur fund-seeking: toward a theory of funding fit in the era of equity crowdfunding. Small Business Economics. https://doi.org/10. 1007/s11187-021-00499-0 Forthcoming

Sudek, R. (2006). Angel investment criteria. Journal of Small Business Strategy, 17, 89-103.

Van Osnabrugge, M. (2000). A comparison of business angel and venture capitalist investment procedures: An agency theory-based analysis. Venture Capital An International Journal of Entrepreneurial Finance, 2, 91-109.

Vismara, S. (2016). Equity retention and social network theory in equity crowdfunding. Small Business Economics, 46, 579-590.

Vismara, S. (2018). Information cascades among investors in equity crowdfunding. Entrepreneurship Theory and Practice, 42, 467-497. 
Walthoff-Borm, X., Schwienbacher, A., \& Vanacker, T. (2018a). Equity crowdfunding: First or last resort? Journal of Business Venturing, 33, 513-533.

Walthoff-Borm, X., Vanacker, T. R., \& Collewaert, V. (2018b). Equity crowdfunding, shareholder structures, and firm performance. Corporate Governance an International Review, 26, 314-330.

Wang, W., Mahmood, A., Sismeiro, C., \& Vulkan, N. (2019). The evolution of equity crowdfunding: Insights from co-investments of angels and the crowd. Research Policy, 48(8), 103727.

Wood, A., Kleinbaum, A. M., \& Wheatly, T. (2019). Cultural diversity broadens social networks SSRN eLibrary.

Zhang, B., Ziegler, T., Mammadova, L., Johanson, D., Gray, M., \& Yerolemou, N. (2018). The 5th UK alternative finance industry report. Centre for alternative finance (CAFE), Judge Business School, University of Cambridge.

Publisher's Note Springer Nature remains neutral with regard to jurisdictional claims in published maps and institutional affiliations. 